\title{
Refinement of a Quantitative Method for Determining the Lime Requirements of Soils
}

\author{
Fernando Abruña and José Vicente \\ INTRODUCTION
}

Probably. the most direct and accurate method of determining the lime requirement of soils is by direct titration using a calcium hydroxide solution. The main disadvantage of this method is the long period of time required before equilibrium between the soil and the solution is attained. This paper reports the results of a study aimed at reducing the time required for equilibrium with this method.

\section{MATERIALS AND METHODS}

Samples of four kaolinitic clay soils, Alonso, Catalina, Cialitos, and Río Piedras were used in this study. Roberts $(2)^{2}$ has described these soils in detail.The soil samples were air-dried and sieved, and their $\mathrm{pH}$, organicmatter content, cation-exchange capacity, and exchangeable bases determined by standard methods. The lime required to neutralize the soil was determined by titration with a calcium hydroxide solution following the method used by Dunn (1).

- The chemical data for the soils studied are summarized in table 1. All the soils were strongly acid and, with the exception of Cialitos I and II, were high in organic matter. This largely accounts for their high exchange capacities. With the exception of Alonso I, the soils were low in exchangeable bases as would be expected of these acid soils rich in kaolinitic clay minerals.

Heating at three different temperatures for varying periods was tested as a means of reducing the time required for the attainment of equilibrium between the soils and the lime solution. In all tests the calcium hydroxide added to the soil was the quantity required to bring it to a pH of 7.0 as previously determined by the standard method.

\section{RESULTS AND DISCUSSION}

Over 100 hours (see table 2) were required to effect equilibrium with all four soils when the standard method was used. A preliminary study showed

${ }^{1}$ Soil Scientist and Project Supervisor, respectively, of a cooperative research Project between the A.R.S. of the U. S. Department of Agriculture and the Agricultural Experiment Station, University of Puerto Rico, Río Piedras, P. R.

2 Numbers in parentheses refer, to Literature Cited, p. 45. 
TABLE 1.-Chemical data obtained on examination of the soils studied

\begin{tabular}{|c|c|c|c|c|c|}
\hline Soil & $\mathrm{pH}$ & Organic matter & $\begin{array}{c}\text { Cation exchange } \\
\text { capacity }\end{array}$ & $\begin{array}{c}\text { Exchangeable } \\
\text { bases }\end{array}$ & $\begin{array}{c}\text { Base to raise } \\
\text { pH of soil to } 7\end{array}$ \\
\hline Alonso I & 5.15 & $\begin{array}{c}\text { Percent } \\
4.48\end{array}$ & $\begin{array}{c}\text { AK.e. } / 100 \mathrm{gm} . \\
20.76\end{array}$ & $\begin{array}{c}\text { M.e. } / 100 \mathrm{gms} \\
10.94\end{array}$ & $\begin{array}{c}\text { Af.e. } \\
11.20\end{array}$ \\
\hline Alonso II & 4.45 & 6.27 & 22.18 & 3.04 & 20.40 \\
\hline Catalina & 4.20 & 9.73 & 31.47 & 2.75 & 30.60 \\
\hline Cialitos I & 5.10 & 2.62 & 14.89 & 3.74 & 10.50 \\
\hline Cialitos II & 4.50 & 2.24 & 14.45 & 1.90 & 13.40 \\
\hline Río Piedras & 4.90 & 3.90 & 16.96 & 3.81 & 12.58 \\
\hline
\end{tabular}

TABLE 2.-The effect of stirring and heating at $85^{\circ} \mathrm{C}$., as compared with boiling, on time required to effect equilibrium between samples of 4 soils and a calcium hydroxide solution

\begin{tabular}{|c|c|c|c|c|c|c|c|c|c|c|c|c|c|c|c|c|}
\hline \multirow{2}{*}{ Soil } & \multicolumn{7}{|c|}{$\begin{array}{l}\mathrm{pH} \text { values at various intervals } \\
\text { (hours) after stirring and } \\
\text { heating to } 85^{\circ} \mathrm{C} \text {. for } 15 \text { minutes }\end{array}$} & \multicolumn{7}{|c|}{$\begin{array}{c}\mathrm{pH} \text { values at various intervals } \\
\text { (hours) after boiling for } \\
5 \text { minutes }\end{array}$} & \multicolumn{2}{|c|}{$\begin{array}{c}\text { Results by } \\
\text { standard method: } \\
\text { Samples stood vithout } \\
\text { heating or stirring }\end{array}$} \\
\hline & 1 & 16 & 24 & 48 & 72 & 96 & 108 & 1 & 16 & 24 & 48 & 72 & 96 & 108 & $\begin{array}{l}\mathrm{pH} \text { at } \\
\text { equi- } \\
\text { librium }\end{array}$ & $\begin{array}{c}\text { Hours } \\
\text { required } \\
\text { to effect } \\
\text { equilibrium }\end{array}$ \\
\hline Cislitos I & 6.90 & 6.85 & 6.80 & 6.80 & 6.80 & 6.80 & 6.82 & 6.90 & 6.83 & 6.80 & 6.80 & 6.80 & 6.85 & 6.85 & 6.90 & 132 \\
\hline Cialitos II & 7.30 & 7.20 & 7.10 & 7.00 & 7.00 & 7.00 & 7.10 & 7.00 & 7.00 & 6.92 & 6.90 & 7.07 & 7.10 & 7.10 & 7.10 & 108 \\
\hline Río Piedras & 6.95 & 6.80 & 6.80 & 6.80 & 6.80 & 6.80 & 6.85 & 6.85 & 6.85 & 6.80 & 6.80 & 6.80 & 6.88 & 6.90 & 6.95 & 108 \\
\hline Catalina & 7.00 & 6.92 & 6.92 & 6.90 & 6.88 & 6.90 & 7.00 & 7.00 & 6.90 & 6.90 & 6.90 & 6.90 & 7.00 & 7.02 & 7.00 & 108 \\
\hline Alonso I & 7.40 & 7.20 & 7.10 & 7.05 & 7.10 & 7.10 & 7.05 & 7.10 & 7.00 & 7.00 & 7.00 & 7.00 & 7.05 & 7.05 & 7.10 & 132 \\
\hline
\end{tabular}

that this period could be reduced to about 50 hours by prolonged stirring or by running the samples in a Waring blendor for 30 minutes.

- The results of a study carried out to determine the effect of temperature and period of heating on the time required to effect equilibrium with samples of two typical soils are shown in table 3. Equilibrium was attained within 2 hours with the Alonso soil heated at $85^{\circ} \mathrm{C}$. for 5 minutes. To attain equilibrium within the same period Catalina soil had to be heated to $85^{\circ} \mathrm{C}$. for 30 minutes. Both soils attained equilibrium within 2 hours when boiled for 5 minutes.

In view of the above results a study was carried out to compare heating at $85^{\circ} \mathrm{C}$. for 15 minutes, accompanied by stirring, with boiling for 5 minutes, using samples of all four soils. The results of this study are summarized in table 2 . The samples merely allowed to stand in contact with the solution following the standard procedure required more than 100 hours to attain equilibrium. With the exception of Alonso $I$ and Cialitos II, which required 24 hours, the soils reached equilibrium within 1 hour with the $85^{\circ} \mathrm{C}$. treatment. Boiling gave the best results since all soils 
TABLE 3.-The effect of 3 different temperature levels and 3 different periods of heating on time required to effect equilibrium between samples of 2 typical soils and a calcium hydroxide solution

\begin{tabular}{|c|c|c|c|c|c|c|c|c|c|}
\hline \multirow{2}{*}{ Soil and process used } & \multicolumn{9}{|c|}{$\mathrm{pH}$ values after number of hours indicated } \\
\hline & 2 & \pm & 6 & 8 & 16 & 24 & 48 & 72 & 96 \\
\hline \multirow{2}{*}{\multicolumn{10}{|c|}{$\begin{array}{l}\text { Alonso clay II: }{ }^{1} \\
\text { Heated at } 50^{\circ} \mathrm{C} \text {. for } \\
\text { time indicated } \\
\text { (minutes)- }\end{array}$}} \\
\hline & & & & & & & & & \\
\hline 5 & 8.08 & 8.00 & 7.70 & - & 一 & - & 7.05 & 6.80 & 6.80 \\
\hline 15 & 8.38 & 7.90 & 7.60 & - & - & - & 7.05 & 6.87 & 6.90 \\
\hline 30 & 8.00 & 7.80 & 7.50 & 一 & - & 一 & 7.05 & 6.80 & 6.80 \\
\hline \multicolumn{10}{|l|}{$\begin{array}{l}\text { Heated to } 85^{\circ} \mathrm{C} \text {. for } \\
\text { time indicated- }\end{array}$} \\
\hline 5 & 7.00 & 7.00 & 7.00 & 7.00 & 6.95 & 6.85 & 6.85 & 6.80 & 6.80 \\
\hline 15 & 7.00 & 6.95 & 6.95 & 6.95 & 6.95 & 6.85 & 6.85 & 6.80 & 6.82 \\
\hline 30 & 6.98 & 6.95 & 6.95 & 6.90 & 6.85 & 6.85 & 6.80 & 6.80 & 6.80 \\
\hline \multicolumn{10}{|l|}{$\begin{array}{l}\text { Boiled for time } \\
\text { indicated- }\end{array}$} \\
\hline 5 & 6.95 & 6.95 & 6.95 & 6.90 & 6.80 & 6.80 & 6.80 & 6.80 & 6.80 \\
\hline 15 & 6.98 & 6.95 & 6.95 & 6.90 & 6.80 & 6.80 & 6.80 & 6.80 & 6.85 \\
\hline 30 & 7.00 & 7.00 & 6.98 & 6.98 & 6.90 & 6.90 & 6.80 & 6.80 & 6.85 \\
\hline \multirow{2}{*}{\multicolumn{10}{|c|}{$\begin{array}{l}\text { Catalina clay }:^{2} \\
\text { Heated to } 50^{\circ} \mathrm{C} \text {. for } \\
\text { time indicated } \\
\text { (minutes)- }\end{array}$}} \\
\hline & & & & & & & & & \\
\hline 5 & 9.40 & 8.90 & 8.40 & 一 & - & - & 7.40 & 7.15 & 7.10 \\
\hline 15 & 8.95 & 8.50 & 8.20 & - & - & - & 7.30 & 7.15 & 7.10 \\
\hline 30 & 8.80 & 8.30 & 8.10 & 一 & - & - & 7.30 & 7.15 & 7.10 \\
\hline \multicolumn{10}{|l|}{$\begin{array}{c}\text { Heated to } 85^{\circ} \mathrm{C} \text {. for } \\
\text { time indicated - }\end{array}$} \\
\hline 5 & 8.30 & 7.90 & 7.75 & 7.60 & 7.20 & 7.10 & 7.05 & 7.00 & 7.00 \\
\hline 15 & 7.65 & 7.45 & 7.30 & 7.15 & 7.00 & 7.00 & 7.00 & 7.00 & 7.00 \\
\hline 30 & 7.20 & 7.15 & 7.15 & 7.15 & 7.00 & 6.90 & 6.90 & 6.90 & 6.90 \\
\hline \multicolumn{10}{|l|}{$\begin{array}{l}\text { Boiled for time } \\
\text { indicated- }\end{array}$} \\
\hline 5 & 7.20 & 7.20 & 7.15 & 7.10 & 7.05 & 7.00 & 7.00 & 7.00 & 7.00 \\
\hline 15 & 7.20 & 7.20 & 7.15 & 7.10 & 7.05 & 7.00 & 7.00 & 7.00 & 7.00 \\
\hline 30 & 7.15 & 7.15 & 7.15 & 7.10 & 7.00 & 6.95 & 6.90 & 6.90 & 6.90 \\
\hline
\end{tabular}

${ }^{1}$ M.e. of base added, 20.4; time required to effect equilibrium using standard method, 108 hours; final $\mathrm{pH}$ by standard method, 7 .

2 M.e. of base added, 30.6; time required to effect equilibrium using standard method, 132 hours; final $\mathrm{pH}$ by standard method, 7.1. 
attained equilibrium with the calcium hydroxide solution within 1 hour. Final $\mathrm{pH}$ values were essentially the same with all treatments.

The data in tables 2 and 3 indicate that, with heating, final $\mathrm{pH}$ values are sometimes about 0.10 unit lower than those obtained by the standard method. This may indicate that equilibrium had not been attained by the standard method even after several days time. It is also possible that heating may have increased the exchange capacity of the soil slightly (possibly through increased hydrolysis of the organic matter), thus resulting in slightly lower $\mathrm{pH}$ values. Heat apparently accelerates neutralization by speeding up the chemical reaction and by completely dispersing the , soil particles.

\section{RECOMMENDED METHOD}

On the basis of the above results the following method is suggested for the rapid, quantitative determination of the lime requirement of soils: Place 10-gm. samples of sieved (mesh 10) air-dry soil in beakers. Dilute with 100 cc. of distilled water and add varying increments of $0.03 \mathrm{~N}$ $\mathrm{Ca}(\mathrm{OH})_{2}$ solution, depending on the expected exchange capacity and base saturation of the soil. Boil on a hot plate for 5 minutes (intermittent stirring of the samples may be necessary to aroid excessive foaming). Cool in a water tray to $25^{\circ} \mathrm{C}$. and determine the $\mathrm{pH}$ of the suspension using a glass electrode. Buffer curves relating $\mathrm{pH}$ values to quantity of lime are then prepared from these data and used to determine the lime required to raise the soil $\mathrm{pH}$ to any desired level.

Good results have been obtained with this method in fieldwork. This method was used in conjunction with a field experiment to determine the lime required to bring a Catalina clay soil to a $\mathrm{pH}$ of 6.5 . The $\mathrm{pH}$ values of paired plots with and without lime 1 year after treatment are given below, the values shown being averages of four samples:

$\begin{array}{rc}\text { Limed } & \text { Unlined } \\ 6.60 & 5.00 \\ 6.58 & 5.00 \\ 6.45 & 4.80 \\ 6.30 & 4.95 \\ \text { Average......... } & .4 .48\end{array}$

\section{SUMMARY}

In determining the lime requirement of kaolinitic soils by direct titration with a calcium hydroxide solution it was found that boiling for 5 minutes reduced the time required for the attainment of equilibrium between the soil and the solution from over 100 hours to 1 hour. The variation in the $\mathrm{pH}$ values of the soils at equilibrium with the two methods 
were in all cases less than 0.1 unit. A precise, rapid laboratory method based on 5-minute boiling is described for determining the lime requirement of these soils. Results of a field experiment are shown to demonstrate the accuracy of the method.

\section{RESUMEN}

Se usó el método de titulación directa con una solución de cal hidratada pàra determinar el requisito calizo de varios suelos kaoliníticos. Se encontró que el tiempo requerido para que el suelo y la solución llegaran a un equilibrio, usando el método corriente, era de más de 100 horas. Este tiempo se redujo a 1 hora haciendo hervir la suspensión por 5 minutos. La variación en los valores de $\mathrm{pH}$ obtenidos por ambos métodos en todos los casos fué de menos de 0.1 unidad. Se describe un método rápido y preciso para determinar el requisito calizo de los suelos kaoliníticos y se presentan datos de un experimento de campo que comprueban la exactitud del método.

\section{LITERATURE GITED.}

1. Dunn, L. E., Lime requirement determination of soils by means of titration curves, Soil Sci. 56 341-51, 1943.

2. Roberts, R. C., Soil Survey of Puerto Rico, U.S.D.A. Series, 1936, No. 8, January 1942. 